\title{
DOSTĘP CUDZOZIEMCA DO AKT W POSTĘPOWANIU W PRZEDMIOCIE ZOBOWIĄZANIA DO POWROTU - UWAGI DE LEGE LATA I DE LEGE FERENDA*
}

\section{WPROWADZENIE}

Decyzja o zobowiązaniu cudzoziemca do powrotu wydawana jest w postępowaniu administracyjnym z zachowaniem szeregu gwarancji procesowych i środków jej kontroli na drodze administracyjnej oraz sądowej ${ }^{1}$. Na podstawie art. 302 ust. 1 pkt 9 ustawy z 12 grudnia 2013 r. o cudzoziemcach ${ }^{2}$ decyzję o zobowiązaniu do powrotu wydaje się cudzoziemcowi, gdy wymagają tego względy obronności lub bezpieczeństwa państwa lub ochrony bezpieczeństwa i porządku publicznego lub interes Rzeczypospolitej Polskiej. Decyzję taką podejmuje organ administracyjny ${ }^{3}$. W tym zakresie organ został jednak zobowiazany przez polskie sądy administracyjne do przeprowadzenia stosownego rozumowania i wskazania na fakty, które przesądzają o istniejącym zagrożeniu ze strony cudzoziemca ${ }^{4}$.

Na mocy art. $73 \S 1$ k.p.a. ustawodawca zapewnił cudzoziemcowi jako stronie postępowania w przedmiocie zobowiazania do powrotu prawo dostępu do akt sprawy, sporządzania z nich notatek, kopii lub odpisów, jak również prawo żądania uwierzytelnienia odpisów z akt sprawy, co musi uzasadnić ważnym interesem. Ustawodawca zastrzegł jednak, że prawa wynikającego z art. 73 $\S 1$ k.p.a nie stosuje się do akt sprawy zawierajacych informacje niejawne

* Artykuł powstał w ramach grantu NCN nr 2015/17/D/HS5/00406 (Sonata 9) na realizacje projektu pt. „Dostęp cudzoziemca do akt w procedurze wydaleniowej w świetle prawa polskiego i europejskiego".

${ }^{1}$ Dąbrowski (2015): 688.

${ }^{2}$ Dz. U. 2013, poz. 1650 ze zm. (dalej jako: u.o.c.). Wymaga podkreślenia, że w obecnie obowiązującej ustawie o cudzoziemcach decyzja o zobowiązaniu cudzoziemca do powrotu zastapiła decyzję o wydaleniu cudzoziemca z terytorium Rzeczypospolitej Polskiej.

${ }^{3}$ Zgodnie z art. 310 u.o.c. decyzję o zobowiązaniu cudzoziemca do powrotu podejmuje: 1) z urzędu - komendant oddziału Straży Granicznej lub komendant placówki Straży Granicznej, który stwierdził istnienie przesłanki uzasadniającej wydanie decyzji o zobowiązaniu cudzoziemca do powrotu; 2) na wniosek wojewody, Ministra Obrony Narodowej, Szefa Agencji Bezpieczeństwa Wewnętrznego, Szefa Agencji Wywiadu, Szefa Służby Kontrwywiadu Wojskowego, Szefa Służby Wywiadu Wojskowego, organu Służby Celnej, komendanta wojewódzkiego lub komendanta powiatowego (miejskiego) Policji - komendant oddziału Straży Granicznej lub komendant placówki Straży Granicznej właściwy ze względu na siedzibę organu występującego z wnioskiem albo miejsce pobytu cudzoziemca.

${ }^{4}$ Zob. wyrok NSA z 31 lipca 2001 r., V SA 501/01. 
o klauzuli tajności „tajne” lub „ściśle tajne”, a także do innych akt, które organ administracji publicznej wyłączy ze względu na ważny interes państwowy (art. 74 ust. 1 k.p.a.). Pojawia się pytanie, co w sytuacji, gdy cudzoziemiec ma zostać zobowiązany do powrotu ze względu na to, że jego dalszy pobyt stanowiłby zagrożenie dla obronności lub bezpieczeństwa państwa, lub ochrony bezpieczeństwa i porządku publicznego albo naruszałby interes Rzeczypospolitej Polskiej, a organ administracyjny, który wydał taką decyzję, nie może przedstawić żadnych dowodów na poparcie tej tezy, ponieważ są tajne. Jeżeli cudzoziemiec nie ma zapewnionego w niezbędnym zakresie dostępu do obciażających go dokumentów uzasadniających podjęcie decyzji o zobowiązaniu do powrotu, tym samym nie ma możliwości przedstawienia w skuteczny sposób swojego stanowiska w przedmiocie tych okoliczności i podjęcia próby zakwestionowania ustaleń dokonanych przez właściwy organ. Niniejszy artykuł ma na celu zbadanie, czy w polskim porządku prawnym istnieją mechanizmy procesowe, które umożliwiają pogodzenie uzasadnionych względów bezpieczeństwa państwa w odniesieniu do charakteru i źródeł informacji branych pod uwagę przy wydawaniu decyzji o zobowiązaniu cudzoziemca do powrotu, z koniecznością zapewnienia cudzoziemcowi korzystania z uprawnień procesowych, takich jak prawo dostępu do akt.

\section{PRAWO DOSTĘPU DO AKT JAKO PRAWO JEDNOSTKI}

W świetle art. 51 ust. 3 Konstytucji RP każdy ma prawo dostępu do dotyczących go urzędowych dokumentów i zbiorów danych. Natomiast art. 51 ust. 4 stanowi, że: „Każdy ma prawo do żądania sprostowania oraz usunięcia informacji nieprawdziwych, niepełnych lub zebranych w sposób sprzeczny $\mathrm{z}$ ustawa" ${ }^{\prime}$. Z treści cytowanych przepisów expressis verbis wynika, że prawa te przysługują każdej jednostce, co oznacza, że nie są ograniczone wyłącznie do obywateli 6 . Zarówno w literaturze, jak i w utrwalonym orzecznictwie Trybunału Konstytucyjnego przyjmuje się, że zagwarantowane w art. 51 ust. 3 i ust. 4 Konstytucji uprawnienia jednostki mieszczą się $\mathrm{w}$ tzw. autonomii informacyjnej jednostki, która „stanowi istotny element składowy prawa do ochrony prywatności, a polega na samodzielnym decydowaniu o ujawnianiu innym podmiotom informacji dotyczących własnej osoby, a także na sprawowaniu kontroli nad tymi informacjami, nawet jeśli znajduja się w posiadaniu innych osób"7. Przyjmuje się bowiem, że ochrona prywatności i autonomii informacyjnej jest konsekwencją ochrony przyrodzonej i niezbywalnej godności człowieka (art. 30 Konstytucji) ${ }^{8}$.

${ }^{5}$ Dz. U. 1997, Nr 78, poz. 483.

${ }^{6}$ Wild (2016): 1232. Zob. także Górzyńska (1999): 38.

${ }^{7}$ Wyrok TK z 23 lipca 2014 r., K 23/11. Zob. także: wyroki TK: z 19 lutego 2002 r., U 3/01; z 20 listopada 2002 r., K 41/02; Garlicki (2003): 2; Wild (2016): 1222.

8 Wild (2016): 1222. 
Należy podkreślić, że konstytucyjne prawo dostępu każdego do dotyczących go dokumentów i zbiorów danych oraz prawo do żądania sprostowania i usunięcia informacji nieprawdziwych, niepełnych lub zebranych w sposób sprzeczny z ustawą pozostają ze sobą w ścisłym związku, uzasadniającym konieczność uprzedniego zapoznania się z informacją zawartą w dokumencieprzez wgląd do dokumentu ${ }^{9}$. W doktrynie podkreśla się, że wskazane prawa jednostki należą do ,standardów sprawiedliwego postępowania administracyjnego, [i] stanowią jeden z istotnych elementów zasady państwa prawnego, wyrażonej w art. 2 Konstytucji" ${ }^{10}$. Trybunał Konstytucyjny stoi na stanowisku, że „prawo dostępu do dokumentów w postępowaniu przed organami władzy publicznej wynika z art. 2 i art. 51 ust. 3 Konstytucji, z kolei prawo strony do wysłuchania w zakresie informacji zebranych przez organ prowadzący postępowanie w sprawie indywidualnej - z art. 2 i art. 51 ust. 4 Konstytucji"11. Jak trafnie wskazuje Zbigniew Kmiecik: „wgląd w akta sprawy stanowi w demokratycznym ustroju konieczny składnik publicznej kontroli administracji, jak również istotną przesłankę takiej relacji między władzą a [jednostka], która opiera się na zaufaniu"12. Prawo dostępu do akt przyczynia się bowiem do właściwego rozpoznania sprawy, gdyż gwarantuje jednostce prawo do przedstawienia swojego stanowiska w przedmiocie informacji, dowodów i dokumentów, na podstawie których organ administracji publicznej zamierza oprzeć swoja decyzję, która może wpłynąć negatywnie na jej sytuację.

Należy zauważyć, że de lege lata omawiane prawo podmiotowe nie ma charakteru absolutnego. Ograniczenie konstytucyjnego prawa jednostki do dostępu do urzędowych dokumentów musi być sformułowane w sposób jasny, pozwalajacy ustalić, w jakiej sytuacji i jakie dokumenty nie podlegają udostępnieniu. Warunki ograniczenia prawa dostępu jednostki do urzędowych dokumentów i zbiorów danych nie mogą być kształtowane dowolnie, musza bowiem być zgodne z zasadą proporcjonalności, o której mowa w art. 31 ust. 3 Konstytucji. Mogą więc być ustanowione wyłącznie w „ustawie i tylko wtedy, gdy są konieczne w demokratycznym państwie dla jego bezpieczeństwa lub porządku publicznego, bądź dla ochrony środowiska, zdrowia i moralności publicznej, albo wolności i praw innych osób. Ograniczenia te nie mogą naruszać istoty wolności i praw"13.

Artykuł $73 \S 1$ Kodeksu postępowania administracyjnego ${ }^{14}$ gwarantuje, iz strona ma prawo wglądu w akta sprawy, sporządzania z nich notatek, kopii lub odpisów, co stanowi konkretyzację na gruncie ustawowym konstytucyjnego prawa dostępu każdej osoby do dotyczących jej urzędowych dokumentów i zbiorów danych, określonego w art. 51 ust. 3 Konstytucji. Jak podkreśla się w doktrynie: „Konstytucyjne prawo dostępu do akt sprawy w postępowa-

${ }^{9}$ Wyrok TK z 27 czerwca 2008 r., K 51/07.

${ }^{10}$ Wyrok TK z 27 czerwca 2008 r., K 51/07.

${ }^{11}$ Wyrok TK z 27 czerwca 2008 r., K 51/07.

12 Kmiecik (2008): 95.

${ }_{13}$ Dz. U. 1997, Nr 78, poz. 483.

${ }_{14}$ Ustawa z 14 czerwca 1960 r. - Kodeks postępowania administracyjnego, Dz. U. Nr 30, poz. 168 (dalej jako: k.p.a.). 
niu administracyjnym należy rozumieć szeroko, nie tylko jako prawo wglądu w akta sprawy, ale także jako prawo do sporządzania z tych akt notatek, kopii lub odpisów, prawo żądania (od organu) uwierzytelnienia odpisów lub kopii akt sprawy, prawo do wydania (przez organ) z akt sprawy uwierzytelnionych odpisów oraz prawo do zapewnienia stronie przez organ administracji publicznej dostępu do pism w formie dokumentu elektronicznego, wnoszonych do organu administracji publicznej lub przez niego doręczanych w swoim systemie teleinformatycznym, po identyfikacji strony w sposób określony w przepisach ustawy o informatyzacji działalności podmiotów realizujacych zadania publiczne" ${ }^{15}$. Umożliwienie stronie zapoznania się z aktami sprawy jest warunkiem sine qua non rzetelnego postępowania oraz korzystania z prawa do obrony. Prawo to przysługuje zarówno w toku, jak i po zakończeniu postępowania. Strona może korzystać z przewidzianych w art. 73 k.p.a. uprawnień albo osobiście, albo przez pełnomocnika. Prawo dostępu do akt obejmuje prawo zapoznania się z całością zgromadzonej w nich dokumentacji, czyli także z tymi dokumentami, które nie miały znaczenia dla treści wydanej decyzji, aczkolwiek zostały zgromadzone $\mathrm{w}$ toku postępowania albo nie zostały dołączone do akt sprawy, chociaż były wykorzystywane w postępowaniu ${ }^{16}$. Co więcej, prawo dostępu do akt daje jednostce również możliwość skorygowania błędu.

Wymaga podkreślenia, że omawiana regulacja jest zwiąana bezpośrednio z podstawowa zasadą postępowania administracyjnego, jaka jest zasada jawności, „która obejmuje m.in. prawo strony do zapoznania się z wszelkimi materiałami zgromadzonymi w sprawie oraz prawo przedstawienia przez stronę swojego stanowiska co do tych materiałów (art. 9, art. 10 i art. $73 \S 1$ k.p.a.). Wyjątki od tej zasady mogą wynikać tylko z ustawy i nie mogą być interpretowane rozszerzająco" ${ }^{17}$. Jawność procesu decyzyjnego niewątpliwie umacnia demokratyczny charakter instytucji oraz zaufanie obywateli do administracji publicznej. W doktrynie panuje pogląd, że prawo dostępu do akt sprawy administracyjnej wynika z zasady jawności względnej ${ }^{18}$.

\section{WYŁĄCZENIE JAWNOŚCI AKT SPRAWY W ŚWIETLE ART. 74 § 1 K.P.A.}

Na podstawie art. $74 \S 1$ k.p.a. organ administracji publicznej nie jest obowiązany umożliwić stronie przeglądanie akt sprawy, sporządzania z nich notatek i odpisów lub wydania jej z akt sprawy uwierzytelnionych odpisów, jeżeli żądanie strony dotyczy akt sprawy zawierajacych informacje niejawne o klauzuli „tajne” lub „ściśle tajne”, a także innych akt, które organ administracji wyłączy ze względu na ważny interes państwowy.

\footnotetext{
15 Wróbel (2016).

16 Chlebny (2008): 58; zob. także Knysiak-Molczyk (2010): 70.

17 Wyrok WSA w Warszawie z 9 stycznia 2012 r., V SA/WA 1692/11.

18 Górzyńska (1999): 252.
} 
Powyższą regulację należy stosować z uwzględnieniem przepisów ustawy z 5 sierpnia 2010 r. o ochronie informacji niejawnych ${ }^{19}$. Ustawa ta reguluje zasady ochrony informacji, które wymagają zabezpieczenia przed nieuprawnionym ujawnieniem. W ustawie określono m.in., jakim informacjom niejawnym nadaje się klauzulę „tajne” lub „ściśle tajne” (art. 5 ust. 1 i 2), a jakim klauzulę „zastrzeżone” lub „poufne” (art. 5 ust. 3 i 4). Informacja, której nadano określoną klauzulę, ma charakter niejawny, co pociaga za sobą skutki w zakresie odpowiedniego z nią postępowania w okresie ochronnym, w szczególności informacja taka może być udostępniona wyłącznie osobie uprawnionej do dostępu do informacji niejawnych. Innymi słowy, powszechny dostęp do tego rodzaju informacji zostaje wyłączony przez fakt nadania jej odpowiedniej klauzuli tajności. Zgodnie z art. 5 ust. 1 ustawy: ,informacjom niejawnym nadaje się klauzulę "ściśle tajne", jeżeli ich nieuprawnione ujawnienie spowoduje wyjątkowo poważną szkodę dla Rzeczypospolitej Polskiej przez to, że: 1) zagrozi niepodległości, suwerenności lub integralności terytorialnej Rzeczypospolitej Polskiej; 2) zagrozi bezpieczeństwu wewnętrznemu lub porządkowi konstytucyjnemu Rzeczypospolitej Polskiej; 3) zagrozi sojuszom lub pozycji międzynarodowej Rzeczypospolitej Polskiej; 4) osłabi gotowość obronną Rzeczypospolitej Polskiej; 5) doprowadzi lub może doprowadzić do identyfikacji funkcjonariuszy, żołnierzy lub pracowników służb odpowiedzialnych za realizację zadań wywiadu lub kontrwywiadu, którzy wykonują czynności operacyjno-rozpoznawcze, jeżeli zagrozi to bezpieczeństwu wykonywanych czynności lub może doprowadzić do identyfikacji osób udzielających im pomocy w tym zakresie; 6) zagrozi lub może zagrozić życiu lub zdrowiu funkcjonariuszy, żołnierzy lub pracowników, którzy wykonują czynności operacyjno-rozpoznawcze, lub osób udzielających im pomocy w tym zakresie; 7) zagrozi lub może zagrozić życiu lub zdrowiu świadków koronnych lub osób dla nich najbliższych albo świadków, o których mowa w art. 184 ustawy z 6 czerwca 1997 r. - Kodeks postępowania karnego (Dz. U. Nr 89, poz. 555 ze zm.), lub osób dla nich najbliższych”. Natomiast w myśl art. 5 ust. 2 u.o.i.n.: ,informacjom niejawnym nadaje się klauzulę "tajne«, jeżeli ich nieuprawnione ujawnienie spowoduje poważną szkodę dla Rzeczypospolitej Polskiej przez to, że: 1) uniemożliwi realizację zadań związanych z ochroną suwerenności lub porządku konstytucyjnego Rzeczypospolitej Polskiej; 2) pogorszy stosunki Rzeczypospolitej Polskiej z innymi państwami lub organizacjami międzynarodowymi; 3) zakłóci przygotowania obronne państwa lub funkcjonowanie Sił Zbrojnych Rzeczypospolitej Polskiej; 4) utrudni wykonywanie czynności operacyjno-rozpoznawczych prowadzonych w celu zapewnienia bezpieczeństwa państwa lub ścigania sprawców zbrodni przez służby lub instytucje do tego uprawnione; 5) w istotny sposób zakłóci funkcjonowanie organów ścigania i wymiaru sprawiedliwości; 6) przyniesie stratę znacznych rozmiarów w interesach ekonomicznych Rzeczypospolitej Polskiej”.

$\mathrm{Z}$ kolei na podstawie art. 5 ust. 3 u.o.i.n.: ,informacjom niejawnym nadaje się klauzulę "poufne», jeżeli ich nieuprawnione ujawnienie spowoduje szkodę dla Rzeczypospolitej Polskiej przez to, że: 1) utrudni prowadzenie bieżącej poli-

19 T.jedn.: Dz. U. 2018, poz. 412 (dalej jako: u.o.i.n.). 
tyki zagranicznej Rzeczypospolitej Polskiej; 2) utrudni realizację przedsięwzięć obronnych lub negatywnie wpłynie na zdolność bojową Sił Zbrojnych Rzeczypospolitej Polskiej; 3) zakłóci porządek publiczny lub zagrozi bezpieczeństwu obywateli; 4) utrudni wykonywanie zadań służbom lub instytucjom odpowiedzialnym za ochronę bezpieczeństwa lub podstawowych interesów Rzeczypospolitej Polskiej; 5) utrudni wykonywanie zadań służbom lub instytucjom odpowiedzialnym za ochronę porządku publicznego, bezpieczeństwa obywateli lub ściganie sprawców przestępstw i przestępstw skarbowych oraz organom wymiaru sprawiedliwości; 6) zagrozi stabilności systemu finansowego Rzeczypospolitej Polskiej; 7) wpłynie niekorzystnie na funkcjonowanie gospodarki narodowej”. $\mathrm{W}$ art. 5 ust. 4 u.o.i.n. przewidziano zaś klauzulę „zastrzeżone”. Klauzulę tę nadaje się informacjom niejawnym: ,jeżeli nie nadano im wyższej klauzuli tajności, a ich nieuprawnione ujawnienie może mieć szkodliwy wpływ na wykonywanie przez organy władzy publicznej lub inne jednostki organizacyjne zadań w zakresie obrony narodowej, polityki zagranicznej, bezpieczeństwa publicznego, przestrzegania praw i wolności obywateli, wymiaru sprawiedliwości albo interesów ekonomicznych Rzeczypospolitej Polskiej”. W orzecznictwie sądów administracyjnych panuje pogląd, że „Ustawodawca, kategoryzując rodzaje informacji niejawnych, czyni to pod katem dóbr prawnie chronionych, używając do tego kwalifikatorów pozwalających na ocenę w tym względzie w warunkach stopniowania zagrożeń w przypadku nieuprawnionego ujawnienia informacji ("spowoduje poważną szkodę", "spowoduje szkodę«). Tego rodzaju zabieg ma przede wszystkim służyć zapewnieniu właściwej ochrony ww. fundamentalnym wartościom, które - postrzegane jako dobrostan Państwa - mają przede wszystkim służyć bezpieczeństwu obywateli” ${ }^{20}$.

Analizując treść art. $74 \S 1$ k.p.a., należy podkreślić, że podstawą odmowy udostępnienia cudzoziemcowi jego akt sprawy może być wyłącznie wzgląd na ochronę informacji niejawnych o klauzuli „tajne” lub „ściśle tajne”. Ustawodawca nie odniósł się w tym przepisie do akt sprawy zawierających informacje niejawne o klauzuli tajności „poufne” lub „zastrzeżone”, jednakże zastrzegł, że de lege lata można odmówić stronie udostępnienia także „innych akt, które organ administracji publicznej wyłączy ze względu na ważny interes państwowy”. Należy przez to rozumieć, że przewidziana w art. $74 \S 1$ k.p.a. możliwość wyłączenia jawności akt ze względu na ważny interes państwowy może uzasadniać w niektórych sytuacjach odmowę udostępnienia akt sprawy objętych klauzula „poufne” lub „zastrzeżone”. Innymi słowy, wyłączenie jawności akt sprawy w stosunku do strony ze względu na ochronę informacji niejawnych oznaczonych klauzula „poufne” lub „zastrzeżone” może nastapić na podstawie art. $74 \S 1$ k.p.a. ze względu na ważny interes państwowy, z uwzględnieniem przepisów ustawy o ochronie informacji niejawnych dotyczących ochrony informacji niejawnych oznaczonych klauzula ,poufne” lub „zastrzeżone”. Podobny pogląd wyraża Andrzej Wróbel: „charakter i rodzaj informacji niejawnych oznaczonych klauzulą "poufne«', wyraźnie wskazuje na ich bezpośredni lub

${ }^{20}$ Wyrok WSA w Warszawie z 13 marca 2012 r., II SA/Wa 2718/11. Zob. także wyrok WSA w Warszawie z 30 stycznia 2013 r., IV SA/Wa 2136/12. 
co najmniej pośredni związek z "ważnym interesem państwowym», o którym mowa w art. $74 \S 1$ k.p.a. ${ }^{21}$ Zwraca też uwagę, że „nie ma przeszkód, aby organ administracji publicznej na podstawie komentowanego przepisu wyłaczał ze względu na ważny interes państwowy także te akta sprawy, które nie są objęte ustawą o ochronie informacji niejawnych. Organ administracji publicznej, działając tu na zasadzie uznania administracyjnego, jest jednak obowiąany wskazać, ze względu na jaki konkretnie ważny interes państwowy wyłączył akta sprawy i dlaczego tak skonkretyzowany interes przemawiał za wyłaczeniem tych akt”22. W orzecznictwie sądów administracyjnych przyjęto, iż: „Pojęcie "ważny interes państwowy» (art. $74 \S 1$ k.p.a.) wymaga indywidualizacji i skonkretyzowania w każdym przypadku przy rozpatrywaniu uprawnienia strony do wglądu akt sprawy. W jego wykładni trzeba bowiem uwzględnić to, że w treści przepisu występuje ono w liczbie pojedynczej, a wobec tego chodzi nie o wszelkie ważne interesy państwowe, lecz o jeden konkretny wskazany. Powoływanie się na ochronę interesu obywatela-autora anonimu, którego danych personalnych organ nie zna i na tej podstawie objęcie tego pisma klauzulą poufne, wydaje się nieporozumieniem"23.

Jeśli chodzi zaś o zakres podmiotowy udostępniania informacji niejawnych w świetle u.o.i.n., to ustawodawca zawęził go wyłącznie do osób, które dają rękojmię zachowania tajemnicy, czyli tych, które spełniają ustawowe wymogi dla zapewnienia ochrony informacji niejawnych przed ich nieuprawnionym ujawnieniem, potwierdzone w wyniku przeprowadzonego postępowania sprawdzającego i tylko w zakresie niezbędnym do wykonywania przez te osoby pracy lub pełnienia służby na zajmowanym stanowisku albo wykonywania czynności zleconych ${ }^{24}$. W literaturze przedmiotu podkreśla się, że „osoba, która w wyniku przeprowadzonego wobec niej postępowania sprawdzającego uzyskała poświadczenie bezpieczeństwa upoważniajace do dostępu do informacji niejawnych oznaczonych klauzula „tajne”, nie jest upoważniona do dostępu do wszystkich informacji niejawnych, które posiadają klauzulę „tajne” (czy też niższa), ale tylko do tych, które są jej niezbędne do realizacji służbowych zadań (zasada need to know)" ${ }^{25}$. Należy jednak wskazać, że art. 4 u.o.i.n. nie stanowi „podstawy do udostępniania akt pełnomocnikom stron”26. Jak wyraźnie stwierdził ustawodawca, przepis ten dotyczy osób wykonujących pracę, pełniących służbę albo wykonujących inną zleconą pracę na rzecz podmiotu, który dysponuje materiałem niejawnym. Zatem jeżeli wobec cudzoziemca toczy się postępowanie w przedmiocie zobowiązania do powrotu na podstawie art. 302 ust. 1 pkt 9 u.o.c. i część akt sprawy stanowią informacje niejawne, którym została nadana klauzula „tajne” lub „ściśle tajne”, to dostępu do nich nie ma ani cudzoziemiec, ani jego pełnomocnik. W takiej sytuacji skuteczna obrona jest niemożliwa lub co najmniej niezwykle utrudniona, jeżeli cudzoziemiec

\footnotetext{
21 Wróbel (2016b).

22 Wróbel (2016b).

${ }^{23}$ Wyrok NSA w Katowicach z 8 września 1997 r., I SA/Ka 298/96.

${ }^{24}$ Art. 4 ust. 1 w zw. z art. 2 pkt 2 u.o.i.n. Zob. także: Stankowska (2014).

25 Stankowska (2014).

${ }^{26}$ Chlebny (2014): 105-106.
} 
jako strona postępowania w przedmiocie zobowiązania do powrotu zostanie pozbawiony możliwości dostępu do zgromadzonego w sprawie materiału dowodowego. Nie znajac zgromadzonego materiału dowodowego, cudzoziemiec ani jego pełnomocnik nie mają możliwości odniesienia się do niego i udowodnienia swoich twierdzeń czy złożenia wyjaśnień.

\section{DOPUSZCZALNOŚĆ OGRANICZENIA PRAWA DOSTĘPU DO AKT W POSTĘPOWANIU W PRZEDMIOCIE ZOBOWIAZZANIA DO POWROTU ZE WZGLĘDU NA OCHRONĘ BEZPIECZEŃSTWA PAŃSTWA}

Uregulowane w $74 \S 1$ k.p.a. ograniczenie prawa strony postępowania do żądania od organu administracji publicznej wglądu do akt sprawy, stanowiące jednocześnie wyjątek od zasady jawności, należy interpretować zgodnie z reguła exceptiones non sunt extendendae oraz z zasada proporcjonalności. Argument ten podnosi również doktryna. Wacław Dawidowicz stwierdza: „iż wyłączenie od wglądu strony do akt ze względu na ważny interes państwowy musi być traktowane jako przypadek nadzwyczajny"27. Wymaga bowiem podkreślenia, że pojęcie „bezpieczeństwo państwa” nie zostało w sposób precyzyjny zdefiniowane pod względem przedmiotowym w przepisach prawa, co stwarza poważne kłopoty w trakcie wykładni norm prawnych i dopuszcza nader zróżnicowane interpretacje pojęcia „bezpieczeństwa państwa”, a tym samym istnieje niebezpieczeństwo daleko idacej dowolności w jego stosowaniu. Pojęcie „bezpieczeństwa państwa” powinno być traktowane w praktyce niezwykle precyzyjnie, co oznacza, że państwo odwołujące się do niego musi wskazać na istnienie niebudzącego wątpliwości, poważnego zagrożenia o charakterze politycznym bądź militarnym dla całego narodu (np. szpiegostwo, akty terroryzmu) ${ }^{28}$.

Z kolei w orzecznictwie sądów administracyjnych panuje pogląd, zgodnie z którym „ograniczenie dostępu strony do akt objętych ochroną tajemnicy państwowej niewątpliwie jest związane z ograniczeniem czynnego udziału strony w postępowaniu i stanowi też potencjalnie zagrożenie dla zasad rzetelnej procedury, ale znajduje podstawę prawną w ustawie (art. 74 ust. $1 \mathrm{Kpa}$ ). Ograniczenie to ma charakter wyjątkowy i związane jest z ochroną wartości nadrzędnej - interesu Rzeczypospolitej Polskiej”29. Należy jednak stwierdzić, że stanowisko to wzbudza kontrowersje pod względem zgodności z zasada proporcjonalności i ochrony praw podstawowych cudzoziemców jako zasadami ogólnymi prawa Unii Europejskiej. Zgodnie z ustalonym stanowiskiem Trybunału Konstytucyjnego stwierdzenie, że ograniczenia mogą być ustanawiane tylko wtedy, gdy sa konieczne w demokratycznym państwie, nakazuje rozważyć, czy wprowadzona przez ustawodawcę regulacja jest w stanie doprowadzić do zamierzonych przez nią skutków, czy regulacja ta jest niezbędna dla ochro-

${ }^{27}$ Dawidowicz (1962): 151.

${ }^{28}$ Nowak (2005): 300.

${ }^{29}$ Wyrok NSA z 31 sierpnia 2005 r., II OSK 655/05. Zob. także: wyroki NSA: z 14 grudnia 2011 r., II OSK 2293/10; z 9 października 2015 r., IV SA/Wa 1949/15. 
ny interesu publicznego, z którym jest związana, czy efekty wprowadzonej regulacji pozostają w odpowiedniej proporcji do ciężarów nakładanych przez nia na jednostkę $e^{30}$. Interes publiczny związany z bezpieczeństwem państwa jest jedna z wartości podlegających ochronie, która jest bezpośrednio wymieniona w art. 31 ust. 3 Konstytucji, co oznacza, że należy do tych przesłanek, których wystapienie może - przy zachowaniu innych wymogów określonych w tym przepisie - uzasadniać zastosowanie zasady proporcjonalności. Innymi słowy, ustawodawca musi wybrać takie środki, które powinny być najskuteczniejsze dla osiagnięcia założonych celów (zachowanie poufności danych związanych z bezpieczeństwem państwa) oraz najmniej uciążliwe dla podmiotów, wobec których mają być zastosowane (dla cudzoziemców korzystających z prawa do obrony w postępowaniu w przedmiocie zobowiązania do powrotu), lub dolegliwe w stopniu nie większym niż jest to niezbędne (konieczne) dla osiagnięcia założonego celu. Należy mieć zatem na uwadze, że konstrukcja przedmiotowego prawa musi zakładać zarówno ochronę interesów państwa, jak i cudzoziemców. Jak trafnie wskazał Sąd Najwyższy: „istnienie wszelkich okoliczności uzasadniajacych rozstrzygnięcie negatywne dla strony musi zostać w sposób bezsporny udowodnione, a prawidłowość tego dowodzenia zarówno w stosunku co do faktu, jak i co do prawa podlega kontroli sądowej”31. Jarosław M. Jankowski podnosi, że: „przyjęcie takiego stanowiska pozwala uniknąć, tak niebezpiecznego w przypadku spraw z udziałem cudzoziemców, sztywnego pojmowania nadrzędności interesu ogólnego nad interesem indywidualnym" 32 .

Nie ulega wątpliwości, że problematyka odmowy cudzoziemcowi dostępu do akt sprawy dotyczącej zobowiązania do powrotu uzasadnionej względami bezpieczeństwa państwa jest złożona. Ratio legis przepisu wyłączającego jawność akt sprawy należy upatrywać w konieczności ochrony nadrzędnego interesu państwa, gdyż - jak podnosi Kmiecik - nieograniczony wgląd w akta sprawy może go naruszać ${ }^{33}$. Wykorzystywanie dowodów niejawnych w postępowaniu w sprawie o zobowiązanie cudzoziemca do powrotu może być czasami konieczne ze względów bezpieczeństwa państwa. Przykładowo, ujawnienie konkretnych, pozyskanych przez organy administracji publicznej informacji dotyczących działań podejmowanych przez cudzoziemca umożliwia w niektórych przypadkach ujawnienie źródła ich pochodzenia, co de facto może zagrażać bezpieczeństwu określonych osób (informatorów, oficerów służb specjalnych) oraz uniemożliwić dalsze pozyskiwanie cennych dla bezpieczeństwa RP informacji lub dokumentów. Co więcej, dokumentacja znajdująca się w aktach sprawy dotyczacej zobowiązania do powrotu może stanowić źródło o stosowanych technikach inwigilacji czy współpracy międzynarodowej między państwami ${ }^{34}$.

Z drugiej jednak strony poufność i brak zewnętrznej kontroli mogą prowadzić do nadmiernej subiektywizacji samego celu informacji (dowodów) niejaw-

\footnotetext{
${ }^{30}$ Wyrok TK z 2 lipca 2007 r., K 41/05. Zob. także: wyrok TK z 31 marca 2008 r., P 20/07.

31 Wyrok SN z 18 listopada 1993 r., III ARN 49/93.

32 Jankowski (2012): 128-140.

33 Kmiecik (2008): 98.

34 Zob. Wojnowska-Radzińska (2017a): 230-245.
} 
nych oraz niezachowania w niej należytej równowagi przy wkraczaniu w prawa i wolności jednostki. Sytuacja taka może również wynikać ze względów ideologicznych czy politycznych w działaniu organów (np. profilowanie rasowe). Innymi słowy, cecha niejawności informacji (dowodów) czyni je podatnymi na nadużycia. Należy mieć zatem na uwadze, że brak ujawnienia cudzoziemcowi dowodów uzasadniajacych wydanie decyzji o zobowiązaniu do powrotu może rodzić uzasadnione wątpliwości w zakresie rzetelności, wiarygodności i bezstronności postępowania w demokratycznym państwie prawnym.

Ponadto w doktrynie panuje pogląd, że w art. $74 \S 1$ k.p.a. „można dostrzec pewne niebezpieczeństwa z punktu widzenia ochrony uprawnienia procesowego podmiotów uprawnionych do wglądu do akt"35. O ile częściowe ograniczenie dostępu cudzoziemca do określonych dokumentów w postępowaniu w przedmiocie zobowiązania do powrotu, które opatrzone są klauzulą tajności - jeśli oczywiście klauzula ta jest zastosowana prawidłowo - można uznać za zgodne z Konstytucją RP i prawem unijnym, o tyle całkowity brak możliwości dostępu do materiałów i akt zgromadzonych w trakcie omawianego postępowania jest nadmiernym ograniczeniem prawa cudzoziemca do dostępu do dotyczacych go dokumentów, niezgodnym z zasadą proporcjonalności, gdyż pozbawia go możliwości ustalenia, na podstawie jakich dokumentów, wskazane w nich dowody, doszło do wydania decyzji o zobowiązaniu do powrotu. Praktyka taka wypacza bowiem zasadę kontradyktoryjności, która winna cechować każde postępowanie sądowe, i tym samym prowadzi do odebrania takiemu postępowaniu waloru bezstronności. Co więcej, całkowity brak możliwości dostępu do zgromadzonych materiałów w toku postępowania w przedmiocie zobowiązania do powrotu nie może być uzasadniany argumentem, że sprawa może być w przyszłości poddana kontroli sądowej, gdyż akta sprawy objęte tajemnica państwową przedstawiane są składowi orzekającemu.

Mimo że argument ten jest podnoszony przez sądy administracyjne, trudno się z nim zgodzić. Po pierwsze, jeżeli cudzoziemiec, jako strona postępowania, ani jego pełnomocnik nie mogą zapoznać się aktami sprawy ze względu na fakt, że znajdują się w nich informacje niejawne stanowiące materialną podstawę wydania decyzji o zobowiązaniu do powrotu, to nie mogą ich również kwestionować przed sądem. Po drugie, tylko na sądzie będzie ciążył obowiązek dokonania za każdym razem oceny, czy ograniczenia w dostępie cudzoziemca w toku postępowania do dokumentów zawierajacych informacje niejawne, stanowiace podstawę wydania decyzji o zobowiązaniu do powrotu, spełniają wymogi testu proporcjonalności, tj. czy rozpoznając sprawę, organ uwzględnił i należycie wyważył interes społeczny ze słusznym interesem strony ${ }^{36}$. W praktyce może się jednak zdarzyć, że takiej oceny sądu po prostu zabraknie. Należy podkreślić, że każdemu etapowi postępowania w przedmiocie zobowiązania do powrotu musza towarzyszyć gwarancje prawa do obrony, adekwatne do danego etapu.

W świetle standardów europejskich przyjętych w Rekomendacji (2004)20 w sprawie sądowej kontroli aktów administracyjnych - organ administracji

35 Górzyńska (1999): 254.

36 Wyrok NSA z 14 grudnia 2011 r., II OSK 1938/10. 
obowiąany jest do przedstawienia sądowi dokumentów i informacji, które maja znaczenie dla sprawy, poza wyjątkowymi sytuacjami przewidzianymi przez prawo krajowe ${ }^{37}$. Autorzy tego dokumentu, powołując się na orzecznictwo Europejskiego Trybunału Praw Człowieka (ETPC), przypominają również o obowiązku umożliwienia stronie zapoznania się z aktami, gdyż jest to warunek rzetelnego postępowania ${ }^{38}$. Jednakże w stosunku do dokumentów zawierających dane podlegające ochronie (np. z powodu bezpieczeństwa państwa) zezwala się na stosowanie specjalnych środków ochrony, aczkolwiek nie sprecyzowano, na czym takie środki mają polegać ${ }^{39}$. Należy w tej kwestii odwołać się do orzecznictwa ETPC, w którym m.in. rozpatrywano zasady korzystania z materiałów poufnych ${ }^{40}$. Trybunał nie wykluczył wprawdzie odmowy udostępnienia stronie akt sprawy ze względu na bezpieczeństwo państwa, ale zalecił stosowanie procedur, które nie zagrażając ujawnieniu natury i źródeł tajnych informacji, przyznaja jednocześnie stronie w pewnym zakresie dostęp do informacji zawartych w aktach administracyjnych i tym samym zapewniaja istotne gwarancje proceduralne ${ }^{41}$.

Przykładem wskazanym przez ETPC jest praktyka stosowana w Kanadzie, polegająca na zapoznawaniu strony ze streszczeniem przebiegu postępowania prowadzonego z wyłączeniem jawności oraz zezwoleniu na udział w postępowaniu obrońcy posiadającego certyfikat dostępu do informacji poufnych (a security-cleared counsel) ${ }^{42}$. Władze Kanady wprowadziły bowiem rozwiązania prawne, które zmierzają do wyważenia praw i przeciwstawnych interesów państwa i cudzoziemca podlegającego wydaleniu. W tym celu prawodawca kanadyjski zapewnił jednocześnie zachowanie poufności danych związanych z bezpieczeństwem państwa i korzystanie z prawa do obrony przez osobę podlegajacca deportacji. W sytuacji gdy dalszy pobyt cudzoziemca na terytorium Kanady zagraża bezpieczeństwu państwa, władze mogą podjąć decyzję o jego wydaleniu. Organ właściwy podpisuje odpowiednie zaświadczenie (certificate), które jest następnie przekazywane sędziemu wraz ze zgromadzonymi informacjami i dowodami będącymi podstawą wydania decyzji o wydaleniu. Zgodnie z art. 78 kanadyjskiej ustawy o imigracji i ochronie uchodźców do sędziego należy ocena, czy wydana decyzja jest uzasadniona ${ }^{43}$. Jednakże dokonanie tej oceny nie jest pozostawione wyłącznie swobodnemu uznaniu sędziego, gdyż ma on obowiązek powołania w toku postępowania tzw. specjalnego obrońcy

37 Art. 4 c Recommendation Rec(2004)20 of the Committee of Ministers to member states on judicial review of administrative acts, 15 grudnia 2004 r., <https://wcd.coe.int/ViewDoc.jsp?id= 802925\&Site=CM $>$ [dostęp: 3.04.2018].

38 Art. 63 memorandum wyjaśniającego, które stanowi integralną część Rekomendacji.

39 Art. 64 memorandum wyjaśniającego.

${ }^{40}$ Chlebny (2005a): 28; zob. także: Chlebny (2005b): 15-38; (2014): 98-110; Kamiński (2012): 21-32; Wojnowska-Radzińska (2017b): 59-71.

${ }^{41}$ Zob. orzeczenie ETPC z 15 listopada 1996 r., Chahal p. Wielkiej Brytanii, skarga nr 22414/93, par. 131 i 144.

${ }^{42}$ Immigration and Refugee Protection Act [IRPA] z 1 listopada 2001 r., dostępny na stronie Ministerstwa Sprawiedliwości Kanady: <http://laws-lois.justice.gc.ca/eng/acts/I-2.5/FullText. html> [dostęp: 20.04.2018].

${ }^{43}$ IRPA. 
(special advocate) $)^{44}$. Funkcję specjalnych obrońców pełnią prawnicy, którzy są niezależni od rządu i sa powoływani przez sąd. Oficjalną listę tych osób sporządza minister sprawiedliwości, korzystając z rekomendacji niezależnej komisji doradczej powołanej do rozpatrywania podań złożonych przez specjalnych obrońcó $w^{45}$. Z art. 85.(1) cytowanej ustawy wyraźnie wynika, że ich rola jest ochrona interesów cudzoziemca podczas rozprawy sądowej, która odbywa się bez udziału cudzoziemca podlegającego wydaleniu i jego pełnomocnika prawnego $^{46}$. Specjalni obrońcy posiadają wymagane przez rząd zezwolenie dostępu do informacji poufnych (security clearance). Minister ds. bezpieczeństwa publicznego jest zobowiązany dostarczyć im kopie wszystkich dokumentów, które sa przekazywane sędziemu, ale nie są udostępniane cudzoziemcowi ani jego pełnomocnikowi ${ }^{47}$. Do głównych zadań specjalnych obrońców należy po pierwsze, możliwość kwestionowania wiarygodności stawianych cudzoziemcowi zarzutów wraz z podważaniem argumentów właściwych organów o utajnieniu pewnych informacji, które nie mogą być ujawnione cudzoziemcowi lub jego pełnomocnikowi ${ }^{48}$. Po drugie, biora udział w rozprawach z wyłączeniem jawności, podczas których są uprawnieni do przesłuchiwania świadków i uczestniczą w weryfikacji dowodów ${ }^{49}$.

Ponadto, w świetle art. 83.1(e) omawianej ustawy sędzia powinien przedstawić cudzoziemcowi streszczenie dowodów i informacji uzyskanych $\mathrm{w}$ toku trwania postępowania, z wyjątkiem tych danych, które są objęte klauzulą tajności ze względu na ochronę bezpieczeństwa państwa, tak żeby osoba ta mogła zapoznać się ze stawianymi jej zarzutami.

Poruszana problematykę dobrze ilustruje także orzecznictwo Trybunału Sprawiedliwości UE (TSUE). Trybunał stwierdził, że powołanie się przez państwo członkowskie na względy związane z bezpieczeństwem państwa nie skutkuje wyłączeniem stosowania prawa Unii, a w szczególności praw podstawowych chronionych przez Kartę praw podstawowych. Nie jest ono także samo w sobie wystarczające, aby uzasadnić brak pełnego i dokładnego poinformowania obywatela Unii o względach uzasadniających decyzję o wydaleniu ${ }^{50}$. Jak trafnie wskazał TSUE: „właściwy sąd danego państwa członkowskiego powinien [...] zastosować metody oraz normy proceduralne pozwalające na pogodzenie z jednej strony prawnie uzasadnionych względów bezpieczeństwa państwa w odniesieniu do charakteru i źródeł informacji branych pod uwagę przy wydawaniu danej decyzji, a z drugiej strony konieczności zagwarantowania stronie w wystarczającym stopniu przestrzegania jej uprawnień procesowych,

\footnotetext{
${ }^{44}$ Art. 83.(1)b IRPA.

${ }^{45}$ Art. 85.(1) IRPA.

${ }^{46}$ Art. 85.1(1) IRPA.

${ }^{47}$ Art. 85.4(1) IRPA.

${ }^{48}$ Art. 85.1(2)(a) IRPA.

${ }^{49}$ Art. 85.1(2)(b) i art. 85.2b IRPA.

${ }^{50}$ Zob. wyrok TSUE z 15 grudnia 2009 r., C-284/05, Komisja Europejska p. Republice
} Finlandii, pkt 36. 
takich jak prawo do [obrony] oraz zasada kontradyktoryjności”51. Co więcej, Trybunał uznał, że w świetle prawa do obrony wyrażonego w art. 47 KPP cudzoziemiec musi zostać powiadomiony o zasadniczej treści względów bezpieczeństwa państwa leżących u podstaw decyzji o jego/jej wydaleniu „w sposób uwzględniający należycie konieczną niejawność dowodów"52.

Reasumując, należy zauważyć, że w polskim porządku prawnym brakuje odpowiednich mechanizmów procesowych, które umożliwiają pogodzenie $\mathrm{z}$ jednej strony uzasadnionych względów bezpieczeństwa państwa $\mathrm{w}$ odniesieniu do charakteru i źródeł informacji branych pod uwagę przy wydawaniu decyzji o zobowiązaniu do powrotu, a z drugiej - konieczności zapewnienia cudzoziemcowi prawa korzystania z uprawnień procesowych, takich jak prawo do dostępu do akt oraz prawo do bycia wysłuchanym. Kierując się więc rozwiązaniami prawnymi przyjętymi w ustawodawstwie kanadyjskim, powinno postulować się wprowadzenie w Polsce regulacji dotyczacych powołania „korpusu specjalnych obrońców”. Sytuacja procesowa tychże osób mogłaby być częściowo wzorowana na zasadach uczestnictwa podmiotów na prawach stron w postępowaniu administracyjnym. Jeżeli decyzja o zobowiązaniu cudzoziemca do powrotu jest uzasadniona przesłanką z art. 302 ust. 1 pkt 9 u.o.c., udział „specjalnego obrońcy” w postępowaniu w przedmiocie zobowiązania do powrotu byłby obligatoryjny.

\section{PODSUMOWANIE}

Konflikt między koniecznością istnienia legalnej, prawnie umocowanej działalności niejawnej organów administracji publicznej a zagrożeniem dla konstytucyjnego prawa cudzoziemca do dostępu do akt w postępowaniu w przedmiocie zobowiązania do powrotu wymaga przede wszystkim wyważenia właściwej proporcji w prawnej ochronie obu dóbr, pozostających w konflikcie. Nie można mówić o osiąnięciu właściwej równowagi wówczas, gdy poziom ochrony materialnoprawnej będzie wysoki, a na poziomie proceduralnym będzie brakowało efektywnych i skutecznych procedur oraz środków umożliwiających realizację prawa cudzoziemca do dostępu do akt. Ustawa z 12 grudnia 2013 r. o cudzoziemcach wymaga zmiany, gdyż nie zawiera przepisów odnoszacych się do możliwości zapoznania się przez cudzoziemca z dowodami i materiałami objętymi klauzulą tajności, potwierdzającymi, że jego dalszy pobyt stanowi zagrożenie dla bezpieczeństwa państwa. Celowe byłoby wyraźne określenie w obowiązującej u.o.c. gwarancji proceduralnych, które zapewniałyby cudzoziemcowi, wobec którego została wydana decyzja o zobowiązaniu do powrotu, podjęcie skutecznej obrony w sytuacji, gdy akta sprawy objęte sa

${ }^{51}$ Wyrok TSUE z 4 czerwca 2013 r., C-300/11, ZZ v. Secretary of State for the Home Department, pkt 57.

${ }^{52}$ Wyrok TSUE z 4 czerwca 2013 r., C-300/11, ZZ v. Secretary of State for the Home Department, pkt 69. Zob. także: Chlebny (2014): 102. 
klauzulą tajności. Istniejącą lukę wypełniłoby powołanie „specjalnych obrońców" na wzór rozwiązań przyjętych w kanadyjskiej ustawie imigracyjnej, którzy mieliby wgląd we wszystkie dokumenty sprawy (wraz z dostępem do informacji tajnych) i działaliby w interesie cudzoziemca, zapewniając rzetelność i sprawiedliwość prowadzonego postępowania.

Julia Wojnowska-Radzińska

Uniwersytet im. Adama Mickiewicza w Poznaniu

juliaw@amu.edu.pl

https: //orcid.org/0000-0003-4443-652X

Dawidowicz, W. (1962). Ogólne postępowanie administracyjne. Zarys systemu. Warszawa.

Dąbrowski, P. (2015). Zobowiązanie cudzoziemca do powrotu, [w:] J. Chlebny (red.), Ustawa o cudzoziemcach. Komentarz. Warszawa: 668-776.

Chlebny, J. (2005a). Sądowa kontrola administracji w świetle rekomendacji Rady Europy. Państwo i Prawo 60(2): 21-33.

Chlebny, J. (2005b). Europejskie standardy procedury administracyjne i sądowoadministracyjnej, [w:] Z. Kmieciak (red.), Postępowanie administracyjne w Europie. Kraków: 15-38.

Chlebny, J. (2008). Udostępnianie stronie akt sprawy administracyjnej a prawo do sądu. Zeszyty Naukowe Sądownictwa Administracyjnego 3: 50-69.

Chlebny, J. (2014). Odmowa dostępu do akt w sprawie administracyjnej. Państwo i Prawo 69(10): $85-97$.

Garlicki, L. (red.) (2003). Konstytucja Rzeczypospolitej Polskiej, Komentarz. Tom 3. Warszawa.

Górzyńska, T. (1999). Prawo do informacji i zasada jawności administracyjnej. Orzecznictwo Sądu Najwyższego, Naczelnego Sądu Administracyjnego i Trybunału Konstytucyjnego. Kraków.

Jankowski, J.M. (2012). Materialne i proceduralne gwarancje obrony interesów cudzoziemców. Glosa do wyroku NSA z 14 grudnia 2011 r., (II OSK 1938/10). Przegląd Sądowy 21(10): 118140.

Kamiński, I.C. (2012). Proceduralne gwarancje związane z wydaleniem cudzoziemca ze względów bezpieczeństwa państwa - uwagi na kanwie sprawy Chakiba Marakachiego. Problemy Współczesnego Prawa Międzynarodowego, Europejskiego i Porównawczego 10: 21-32.

Knysiak-Molczyk, H. (2010). Prawo do informacji w postępowaniu administracyjnym, sądowoadministracyjnym oraz w ustawie o dostępie do informacji publicznej. Przegląd Prawa Publicznego 3: 66-79.

Kmiecik, Z. (2008). Zakres udostępniania akt sprawy w postępowaniu administracyjnym. Ruch Prawniczy, Ekonomiczny i Socjologiczny 70(2): 95-107.

Nowak, M. (2005), U.N. Covenant on Civil and Political Rights. CCPR Commentary, 2nd edn. N.P. Engel.

Wild, M. (2016). Komentarz do art. 51 Konstytucji RP, [w:] L. Bosek, M. Safjan (red.), Konstytucja RP. Tom 1: Komentarz do art. 1-86. Warszawa: 1226-1235.

Wojnowska-Radzińska, J. (2017a). The access to secret evidence in expulsion proceedings under the European Convention on Human Rights. Netherlands Quarterly of Human Rights 35(4): $230-245$.

Wojnowska-Radzińska, J. (2017b). Zakaz arbitralnego wydalania cudzoziemców w świetle art. 1 Protokołu nr 7 do EKPC i jego realizacja w polskim prawie i praktyce - wybrane problemy. Ruch Prawniczy, Ekonomiczny i Socjologiczny 79(1): 59-71.

Wróbel, A. (2016a). Komentarz aktualizowany do art. 73 Kodeksu postępowania administracyjnego. System informacji prawnej [Online]. Lex/el.

Wróbel, A. (2016b). Komentarz aktualizowany do art. 74 Kodeksu postępowania administracyjnego. System informacji prawnej [Online]. Lex/el. 


\section{AN ALIEN'S ACCESS TO THE FILES \\ IN PROCEEDINGS CONCERNING THE OBLIGATION TO RETURN \\ - COMMENTS DE LEGE LATA AND DE LEGE FERENDA}

\section{Sum mary}

Aliens who are parties to expulsion proceedings have the right to view their files, make notes and copies, and demand that notes or copies of the case files be authenticated. In each case, this must be justified by the interests of the party (Article 73(1) and (3) of the Code of Administrative Procedure [CAP]). However, the legislator stipulated that the law provided for in Article 73 of the CAP shall not apply to case files which contain classified information ('secret' or 'top secret'), neither shall it apply to other files that the public administration body has excluded due to their being contrary to State interests (Article 74(1) the CAP). This means that records of the proceedings are available neither to the party nor the counsel. The aim of this paper is, therefore, to examine whether the Polish legal order includes procedural mechanisms which accommodate, on the one hand, legitimate State security considerations regarding the nature and sources of the information taken into account in the adoption of decision obliging foreigners to return and, on the other hand, the need to ensure sufficient compliance with an aliens' procedural rights, such as the right of access to the files and the right to a defence.

Keywords: access to files; alien; classified information; decision obliging an alien to return; principle of proportionality 
